\title{
A quality assessment of crude palm oil marketed in Bahia, Brazil
}

\author{
By D.T. de Almeida ${ }^{1,}$, I.L. Nunes ${ }^{1}$, P.L. Conde ${ }^{2}$, R.P.S. Rosa ${ }^{2}$, \\ W.F. Rogério ${ }^{1}$ and E.R. Machado ${ }^{2}$
}
${ }^{1}$ Escola de Nutrição, Departamento de Ciência dos Alimentos, Universidade Federal da Bahia, Av. Araújo Pinho, 32, Canela, Salvador-Bahia, CEP: 40110-150, Brazil
${ }^{2}$ Fundação Oswaldo Cruz, Instituto Nacional de Controle de Qualidade em Saúde (INCQS), Av. Brasil, 4365, Manguinhos, Rio de Janeiro-RJ, CEP: 21040-900, Brazil
Corresponding author: deliata@uol.com.br and delia@ufba.br

\section{RESUMEN}

Evaluación de la calidad del aceite de palma crudo comercializado en Bahía, Brasil

Las características de calidad del aceite de palma crudo (CPO) y oleína de palma cruda (CPOL) producidos en los estados de Bahía y Pará fueron investigados. Se analizaron doce muestras de aceites; 2 (CPO) eran de Pará (producido industrialmente), mientras que las otras 10 procedían de Bahía (3 CPOs y 3 CPOLs producidos industrialmente, mientras que 1 CPOL y 3 CPOs fueron procesadas tradicionalmente). El análisis químico incluyó la determinación de ésteres metílicos de ácidos grasos (FAME), ácidos grasos libres (FFA\%), índice de peróxido $(\mathrm{PV})$, el tiempo de inducción $(\mathrm{TI})$, los carotenoides totales (TC) y el total de compuestos polares (TPC). Los principales ácidos grasos saturados en estas muestras fueron pal-

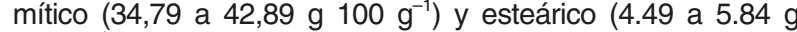
$\left.100 \mathrm{~g}^{-1}\right)$, y los principales ácidos grasos insaturados fueron

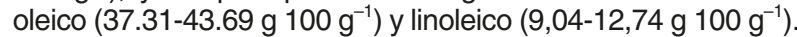
Todas las muestras producidas en Bahía muestran valores de FFA $(6,77-13,49 \%)$ y TPC $(13,71$ a $19,50 \%)$, por encima de los niveles de los estándares internacionales de calidad, a diferencia de las muestras producidas en Pará. TC, PV y TPC oscilaron entre 422,1 a 584,2 $\mu \mathrm{g} \mathrm{g}^{-1}, 1,32$ a 3,7 meq $\mathrm{O}_{2} \mathrm{~kg}^{-1}$ y 1,72 a $4,66 \mathrm{~h}$, respectivamente. PV, FFA y TPC se correlacionan inversamente con TC y IT. El uso de procesos inadecuados de extracción de aceites en Bahía se está convirtiendo claramente en un problema de seguridad alimentaria.

PALABRAS CLAVE: Aceite crudo de palma - Ácido graso - Ácido graso libre - Carotenoides - Índice de peróxidos - Oleína de palma cruda.

\section{SUMMARY}

A quality assessment of crude palm oil marketed in Bahia, Brazil

The characteristics of the quality of crude palm oil (CPO) and crude palm olein (CPOL) produced in the states of Bahia and Pará were investigated. Twelve oil samples were analyzed; 2 (CPO) were from Pará (produced industrially), while the other 10 were from Bahia (3 CPOs and 3 CPOLs produced industrially, while $1 \mathrm{CPOL}$ and $3 \mathrm{CPO}$ were traditionally processed). The chemical analyses included the determination of fatty acid methyl esters (FAME), free fatty acids (FFA\%), peroxide value (PV), induction time (IT), total carotenoids (TC) and total polar compounds (TPC). The major saturated fatty acids in these samples were palmitic (34.79-42.89 $\left.\mathrm{g} 100 \mathrm{~g}^{-1}\right)$

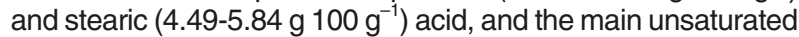

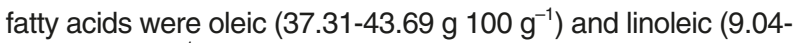

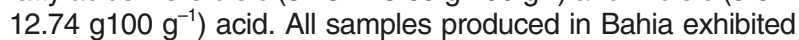
higher FFA (6.77-13.49\%) and TPC (13.71-19.50\%) levels than permitted in the international quality standards, unlike the samples produced in Pará. TC, PV and IT ranged from 422.1 to $584.2 \mu \mathrm{g} \mathrm{g}^{-1}$, 1.32 to $3.7 \mathrm{meq} \mathrm{O}_{2} \mathrm{~kg}^{-1}$ oil and 1.72 to $4.66 \mathrm{~h}$, respectively. PV, FFA and TPC were inversely correlated with TC and IT. The use of inappropriate oil extraction processes in Bahia is clearly becoming a food safety problem.

KEY-WORDS: Carotenoids - Crude palm oil - Crude palm olein - Fatty acid - Free fatty acid - Peroxide value.

\section{INTRODUCTION}

The palm fruit (Elaeis guineensis Jacq.) is the source of both palm oil (extracted from the palm fruit) and palm kernel oil (extracted from the fruit seeds) (Edem, 2002; Lin, 2011). Malaysia, Indonesia and Nigeria are the major producers of palm oil (Berger, 2005). The production areas in Brazil are found in the states of Amazonas, Amapá, Bahia and Pará, which account for $80 \%$ of the domestic production of this oil (Gomes et al., 2008).

In Brazil, crude palm oil is known as azeite de dendê and is an ingredient in most dishes from Bahia, such as moquecas, vatapá, xinxin de galinha, caruru, and akara. Akara is now regarded as one of Brazil's irreplaceable national treasures (IPHAN, 2005). This dish is prepared from several varieties of cowpea (Vigna unguiculata L.Walp). To prepare akara, the beans are split, decorticated, and macerated into a paste. After being seasoned with grated onion and salt, the paste is whipped, shaped into balls with a wooden spoon and deep fried in crude palm oil (Mesquita, 2002). The dish has been commercialized on the streets of Salvador by baianas de acarajé women who are easily recognizable by their all-white cotton dresses, headscarves and caps.

In Brazil, similar to Nigeria (Akusu et al., 2000) and Cameroon (Frank et al., 2011), the oil is extracted by different methods in different locations, and this oil production is an important support of home agriculture. Palm fruit oil processing in Bahia may be categorized into two methods; traditional 
vs. industrial. In both methods, palm plantations are often very far from local processing plants. The palm fruit is harvested when the fruits are ripe. The fruit is manually threshed by cutting the fruitladen spikelets from the bunch stem with an axe or machete and then separating the fruit from the spikelets by hand. The fruit is then transported by animal or truck for delivery in the courtyards of industries and/or farms, which means a week or more before processing (Gomes et al., 2008).

According to traditional methods, the fruit processing is followed by maceration and pilling, or the fruit is placed in a Rodão, an animal-driven instrument that consists of a stone or cement wheel that crushes oil from the palm fruits (Mesquita, 2002). The mixture is placed with water in a half gallon container or any vessel that can be heated. After extraction, the recovered oil is heated again to remove the residual water and, when cool, is bottled and stored for consumption (Gomes et al., 2008).

The oil industry in Bahia is concentrated in 5 small and medium-sized companies. These companies produce the oil in the following stages: bunch sterilization at $130^{\circ} \mathrm{C}$ and bunch threshing; fruit digestion between $80-90^{\circ} \mathrm{C}$; and pressing, clarification, oil drying and storage (Gomes et al., 2008). The extraction methods in Bahia and Pará are quite different. In Pará, the plantations are near the oil-producing companies, and the bunches are harvested when the fruits are at optimum ripeness, handled with care to avoid bruising, and immediately processed and sterilized with pressurized steam.

Palm oil has a balanced fatty acid composition in which the levels of saturated fatty acids (44\%) and unsaturated fatty acids (50\%) are nearly equal. Palmitic acid (44-45\%) and oleic acid (39-40\%) are the major components, while linoleic acid comprises a smaller fraction (10-11\%), and there is only a trace amount of linolenic acid (0.1-0.4\%). The low level of linoleic acid and the virtual absence of linolenic acid make the oil relatively stable for deep frying (Berger, 2005). By fractionation, one liquid fraction (palm olein, rich in unsaturated compounds) and one solid fraction (palm stearin, rich in saturated compounds) can be obtained and used for different purposes in the food industry (CODEX 210, 2011; Lin, 2011). In addition, crude palm oil is rich in carotenoids and has a high content of vitamin $\mathrm{E}$, present as tocopherols and tocotrienols (Berger, 2005; Lin, 2011).

The aim of this research was to assess the chemical quality of crude palm oil and crude palm olein marketed in Salvador-Bahia, Brazil and used to deep-fry akara. The results of this study may support government and industry actions aimed at improving the quality of this oil.

\section{MATERIALS AND METHODS}

\subsection{Collection of oil samples}

A semi-structured questionnaire distributed to 149 bahianas de acarajés in 12 health districts of Salvador was used to select samples (Curvello, 2010). Baianas reported which types of crude palm oil and crude palm olein were used to manufacture akara and where these materials were purchased. Samples were collected at grocery stores and/ or fairs and supermarkets in the city of Salvador. Twelve samples were collected: three CPO samples $(1,2$, and 3$)$ and three crude palm olein samples (CPOLs) $(4,5$, and 6) which were produced by traditional methods in Bahia, one CPOL (7) and three CPO samples (8, 9, and 10) which were industrially produced locally, and two samples of CPO (11 and 12) were industrially produced in Pará (Table 1). The fractions (stearin and olein) separate spontaneously during packaging, with most of the stearin deposited at the bottom of the container and olein layered above. These products are marketed

Table 1

Characteristics of crude palm oil (CPO) and crude palm olein (CPOL) marketed in Salvador-Bahia

\begin{tabular}{clccc}
\hline Samples & Producer region & Types of oil & Extraction Method & Manufacturing time \\
\hline 1 & Nazaré/Bahia & CPO & Traditional & $\mathrm{NI}$ \\
2 & Valença/Bahia & $\mathrm{CPO}$ & Traditional & $\mathrm{NI}$ \\
3 & Valença/Bahia & $\mathrm{NI}$ & Traditional & $\mathrm{NI}$ \\
4 & Taperoá/Bahia & CPOL & Industrial & 3 months \\
5 & Nazaré/Bahia & CPOL & Industrial & $\mathrm{NI}$ \\
6 & Nazaré/Bahia & CPOL & Industrial & 11 months \\
7 & Taperoá/Bahia & CPOL & Traditional & 7 months \\
8 & Taperoá/Bahia & CPO & Industrial & 1 month \\
9 & Valença/Bahia & IPO & Industrial & 2 months \\
10 & Nilo Peçanha/Bahia & CPO & Industrial & 1 months \\
11 & Castanhal/Pará & CPO & Industrial & $\mathrm{NI}$ \\
\hline
\end{tabular}

$\mathrm{NI}=$ not informed $; \mathrm{CPO}=$ Crude Palm Oil $; \mathrm{CPOL}=$ Crude Palm Olein . 
as the olein fraction and are presented as a liquid suspension. Both sample types were stored at room temperature in plastic bottles and exposed to direct sunlight. After collection, the samples were transported to the laboratory in thermal containers, homogenized and stored in $100 \mathrm{~mL}$ amber glass bottles at $-18^{\circ} \mathrm{C}$ until analysis.

\subsection{Analytical determination}

\subsubsection{Fatty acid methyl esters (FAME)}

Fatty acids were transformed to their methyl esters following the method of Institute Adolfo Lutz (2005) and were determined with a Shimadzu, Model 17A gas chromatograph (Shimadzu, Japan) equipped with a flame ionization detector (FID), split/splitless injector, and CP-Sil 88 capillary column (100 $\mathrm{m} \times 0.25$ i.d., $0.25 \mu \mathrm{m}$ film thickness) (CP 7420 Varian, EUA). The operation parameters were as follows: column temperature held at $45^{\circ} \mathrm{C}$ for $2 \mathrm{~min}$, then increased at $20^{\circ} \mathrm{C} \mathrm{min}^{-1}$ to $165^{\circ} \mathrm{C}$ and held at this temperature for $15 \mathrm{~min}$, and then increased at $4^{\circ} \mathrm{C} \mathrm{min}^{-1}$ until $220^{\circ} \mathrm{C}$ (35 min). The injector and detector were kept at $250^{\circ} \mathrm{C}$. The gas flow rates used were $1 \mathrm{~mL} \mathrm{~min}^{-1}$ carrier gas (He), $30 \mathrm{~mL} \mathrm{~min}^{-1}$ for $\mathrm{H}_{2}$ and $300 \mathrm{~mL} \mathrm{~min}^{-1}$ for synthetic air. The sample split mode was $1 / 40$. The injections were performed in duplicate, and the double injection volume was $1 \mu \mathrm{L}$. For the fatty acid identification, the retention times were compared to those of standard methyl esters (Sigma, St. Louis, $\mathrm{MO}, \mathrm{USA}$ ). For quantification (in $\mathrm{g}$ fatty acid $100 \mathrm{~g}^{-1}$ of total lipids), tricosanoic acid methyl ester from Sigma (USA) was used as an internal standard (23:0) at $2.5 \mathrm{mg} \mathrm{mL}^{-1}$ in n-hexane. Theoretical FID correction factor (Visentainer and Franco, 2012) values were used to obtain the concentration values. Fatty acid contents were reported in $\mathrm{g}$ per $100 \mathrm{~g}$ of total lipids with the following Equation (1):

\section{$F A=A X^{*} W I S * C F x / A I S * W x{ }^{*} C F A E$}

where $F A$ is $g$ of fatty acids per $100 \mathrm{~g}$ of total lipids, $A X$ is the peak area (fatty acid methyl esters), AIS is the peak area of the internal standard (IS) (tricosanoic acid methyl ester (23:0)), WIS is the IS weight ( $\mathrm{g}$ ) added to the sample (in $\mathrm{g}$ ), WX is the sample weight (in $\mathrm{g}$ ), CFX is the theoretical correction and CFAE is the conversion factor necessary to express the results as $\mathrm{g}$ of fatty acids rather than as methyl esters.

\subsubsection{Rancimat stability test}

The oxidative stability of the oil samples was determined with a Rancimat 743 (Metrohm AG, Switzerland). In brief, $3 \mathrm{~g}$ of the vegetable oil were weighed into the reaction vessel and heated at $120^{\circ} \mathrm{C}$ with an air flow of $10 \mathrm{~L} \mathrm{~h}^{-1}$. The volatile products released during the oxidation process were collected in a flask containing distilled water. The oxidation process was recorded automatically by measuring the change in conductivity of the distilled water due to the formation of volatile compounds and the oil stability index (OSI), which is expressed in hours (h) (Läubli and Bruttel, 1986). At each time point, eight oil samples were analyzed simultaneously by the equipment. Each sample was analyzed in duplicate.

\subsubsection{Free fatty acids (FFA \%) and peroxide value $(P V)$}

Fatty acids and peroxide were analyzed in triplicate according to AOCS Ca 5a-40 (AOCS, 1992) and AOCS Cd 8-53 (AOCS, 1990), respectively.

\subsubsection{Total Polar compounds}

The total polar compound (TPC) content was determined gravimetrically according to a mini column method described previously, with slight modification (Dobarganes et al., 2000). In brief, approximately $0.5 \mathrm{~g}$ of crude palm oil were dissolved in the elution solvent and introduced into a glass column filled with a slurry of silica gel and elution solvent. The elution solvent was a mixture of light petroleum (b.p. $40-60^{\circ} \mathrm{C}$ ) and diethyl ether 94:6 (v:v). A chromatographic glass column with an internal diameter of $1 \mathrm{~mm}$ and a length of $15 \mathrm{~mm}$, containing $5 \mathrm{~g}$ of silica gel (with a particle size 0.063$0.200 \mathrm{~mm}$ and $70-230 \mathrm{mesh}$ ) adjusted to a water content of $5 \%$ was used. Non-polar compounds were eluted with $60 \mathrm{~mL}$ of the elution solvent, and the polar compound fraction was eluted with $50 \mathrm{~mL}$ diethyl ether. A dropping funnel was used, and the flow rate was adjusted to approximately $1.5 \mathrm{~mL}$ $\mathrm{min}^{-1}$. The solvent was removed by rotary evaporation, and the flask was flushed with a stream of nitrogen to ensure dryness. The completeness of the fractionation was evaluated by analytical thin-layer chromatography (TLC) with an elution system of petroleum ether:diethyl ether:acetic acid (70:40:1; v:v:v).

\subsubsection{Total carotenoids (TC)}

Crude palm oil samples $( \pm 0.2-0.3 \mathrm{~g}$ ) were dissolved in petroleum ether and quantified in a Lambda 25 UV-Vis spectrophotometer (Perkin Elmer, Singapore) at $450 \mathrm{~nm}$ with an absorption coefficient $\left(A^{1 \%}{ }_{1 \mathrm{~cm}}\right)$ of 2592 (Davies, 1976). The analysis was performed in triplicate.

\subsection{Data analysis}

Statistical analyses were performed with SPSS 13.0.1 for Windows (SPSS Inc., 2003). Levene's test for equalizing variances was statistically significant for all the parameters with the exception of the free fatty acid, for which the Tamhane's and Tukey methods were followed. The linear correlation between the two parameters was assessed by Spearman's ( $r$ ) rank correlation coefficient. 


\section{RESULTS AND DISCUSSION}

\subsection{Fatty acid methyl esters (FAME)}

Crude palm oil (CPO) has a balanced fatty acid composition in which the level of saturated fatty acids is almost equal to the level of unsaturated fatty acids (Table 2). The major saturated fatty acids

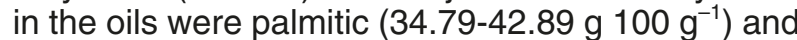

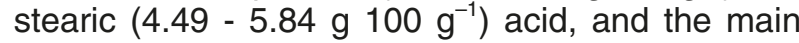
unsaturated fatty acids were oleic (37.31- $43.69 \mathrm{~g}$

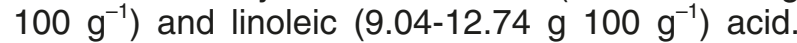
Only a trace amount of linolenic acid was detected, and $50 \%$ of the samples included $\mathrm{C} 18: 3$ with trans isomerism (0.12-0.34 g $100 \mathrm{~g}^{-1}$ ) (Table 2). These saturated and unsaturated fatty acids values were within the range of previously published results for Brazilian palm oils (Tavares and Barbério, 1989). In the previous study, the authors concluded that the oil in the survey was more unsaturated than Nigerian oils, with an exceptionally broad range of palmitic acid (32-57\%) and oleic acid (34-47\%) contents, and consisted of mixtures of oil of Elaies oleifera with various proportions of stearin. The oils produced in Bahia are packaged in plastic bottles at room temperature and spontaneously separate into the liquid fraction (olein) and a more solid fraction (stearin) in variable amounts. The following saturated/polyunsaturated ratios were observed for traditional samples $(1,2$, and 3$)$, industrial samples $(8,9,10,11$, and 12$)$ and samples of olein $(4,5$, 6, and 7): 0.93-0.98, 0.86-0.94 and 0.83-0.86, respectively.

\subsection{Free fatty acids (FFA \%)}

The FFA\% content is the most commonly used criterion for determining the quality of crude palm oil; the FFA content must not exceed $5 \%$ as oleic acid or palmitic acid according to CODEX 210, (2011) and PORAM (2013), respectively. FFA is formed due to the hydrolysis of triacylglycerol by lipase in the mesocarp of the palm fruit. This enzyme is activated at maturity upon bruising and/or wounding of the fruit or, to some extent, by microbial contamination (Ebonguea et al., 2006).

The mean values of the FFA\% for the traditionally and industrially processed CPO in Bahia were $9.92 \% \pm 0.06$ and $9.03 \% \pm 0.06$, respectively, while the FFA \% values for traditionally and industrially extracted olein were $9.03 \% \pm 0.45$ and $10.89 \pm 0.07 \%$, respectively. By contrast, the FFA $\%$ content of industrially processed Pará oil was $2.38 \% \pm 0.03$, much lower than that of the Bahia oil (Table 3). Overall, the FFA \% values of all samples produced in Bahia were higher than those established by CODEX 210, 2011, and the mean FFA \% values of the oil samples extracted mechanically were slightly higher than those extracted by traditional methods (Table 3). Conversely, the FFA \% values of oil samples extracted in the state of Pará were below the $5 \%$ limit (Table 3 ) and similar to the values obtained for crude palm oil from Malaysia (3-4\%) (Hadi et al., 2012).

These results may reflect a lack of care during fruit harvesting, transportation, sanitation and processing in the state of Bahia (Gomes et al., 2008). The

Table 2

Fatty acids composition ( $100 \mathrm{~g} \mathrm{~g}^{-1}$ ) of crude palm oil (CPO) and crude palm olein (CPOL) marketed in Salvador-Bahia

\begin{tabular}{|c|c|c|c|c|c|c|c|c|c|c|c|c|c|}
\hline \multicolumn{14}{|c|}{ FAME g $100 \mathrm{~g}^{-1}$} \\
\hline Samples* & $\mathrm{C} 12: 0$ & $\mathrm{C} 14: 0$ & $\mathrm{C} 16: 0$ & C16:1 & C18:0 & C18:1 & C18:2 & $\mathrm{C} 20: 0$ & $\mathrm{C} 18: 3 \mathrm{t}$ & C18:3 & SFA & MUFA & PUFA \\
\hline $1 \mathrm{CPO}$ & & $0.75 \pm 0.00$ & $42.79 \pm 0.07$ & & $5.77 \pm 0.00$ & $39.62 \pm 0.05$ & $10.35 \pm 0.01$ & $0.41 \pm 0.00$ & & $0.67 \pm 0.19$ & $49.72 \pm 0.07$ & $39.62 \pm 0.05$ & $11.02 \pm 0.20$ \\
\hline $2 \mathrm{CPO}$ & & $0.75 \pm 0.00$ & $42.89 \pm 0.12$ & & $5.77 \pm 0.01$ & $39.68 \pm 0.07$ & $10.36 \pm 0.04$ & $0.43 \pm 0.02$ & 0.34 & $0.32 \pm 0.01$ & $49.84 \pm 0.15$ & $39.68 \pm 0.07$ & $10.68 \pm 0.05$ \\
\hline $3 \mathrm{CPO}$ & $0.28 \pm 0.00$ & $0.85 \pm 0.00$ & $40.73 \pm 0.02$ & 0.18 & $5.36 \pm 0.00$ & $40.70 \pm 0.05$ & $10.00 \pm 0.02$ & $0.62 \pm 0.07$ & & $0.30 \pm 0.00$ & $47.84 \pm 0.09$ & 40.88 & $10.30 \pm 0.02$ \\
\hline $4 \mathrm{CPOL}$ & $0.36 \pm 0.00$ & $0.81 \pm 0.00$ & $38.25 \pm 0.05$ & & $5.66 \pm 0.00$ & $41.80 \pm 0.14$ & $12.28 \pm 0.14$ & $0.36 \pm 0.00$ & $0.27 \pm 0.00$ & $0.45 \pm 0.00$ & $45.49 \pm 0.11$ & $41.8 \pm 0.01$ & $12.75 \pm 0.01$ \\
\hline $5 \mathrm{CPOL}$ & $0.72 \pm 0.02$ & $1.06 \pm 0.02$ & $37.47 \pm 0.71$ & $0.19 \pm 0.00$ & $4.49 \pm 0.06$ & 39.900 .67 & $10.73 \pm 0.20$ & $0.41 \pm 0.04$ & & $0.27 \pm 0.01$ & $44.15 \pm 0.85$ & $40.09 \pm 0.67$ & $11.00 \pm 0.21$ \\
\hline $6 \mathrm{CPOL}$ & $0.64 \pm 0.01$ & $1.07 \pm 0.01$ & $39.07 \pm 0.09$ & 0.21 & $4.80 \pm 0.00$ & 40.150 .01 & $12.74 \pm 0.02$ & $0.36 \pm 0.00$ & & $0.31 \pm 0.01$ & $45.94 \pm 0.11$ & 40.36 & $13.05 \pm 0.03$ \\
\hline $7 \mathrm{CPOL}$ & $0.46 \pm 0.01$ & $0.80 \pm 0.03$ & $36.08 \pm 0.73$ & 0.14 & $5.31 \pm 0.08$ & $41.31 \pm 0.76$ & $9.71 \pm 0.20$ & $0.39 \pm 0.01$ & 0.16 & $0.29 \pm 0.01$ & $43.04 \pm 0.86$ & 41.45 & $10.00 \pm 0.21$ \\
\hline $8 \mathrm{CPO}$ & $0.34 \pm 0.00$ & $0.83 \pm 0.01$ & $40.95 \pm 0.02$ & 0.17 & $5.78 \pm 0.01$ & $39.18 \pm 0.04$ & $11.40 \pm 0.04$ & $0.37 \pm 0.01$ & 0.12 & $0.29 \pm 0.00$ & $48.27 \pm 0.05$ & 39.35 & $11.69 \pm 0.04$ \\
\hline $9 \mathrm{CPO}$ & $0.36 \pm 0.01$ & $0.66 \pm 0.02$ & $34.79 \pm 0.79$ & $0.09 \pm 0.00$ & $5.45 \pm 0.13$ & $37.31 \pm 0.85$ & $9.04 \pm 0.19$ & $0.38 \pm 0.01$ & & $0.15 \pm 0.00$ & $41.64 \pm 0.96$ & $37.4 \pm 0.85$ & $9.19 \pm 0.19$ \\
\hline $10 \mathrm{CPO}$ & $0.44 \pm 0.00$ & $0.82 \pm 0.00$ & $39.11 \pm 0.21$ & & $5.84 \pm 0.03$ & $40.44 \pm 0.25$ & $11.93 \pm 0.08$ & $0.37 \pm 0.02$ & & $0.28 \pm 0.00$ & $46.58 \pm 0.26$ & $40.44 \pm 0.25$ & $12.21 \pm 0.08$ \\
\hline $11 \mathrm{CPO}$ & $0.25 \pm 0.00$ & $0.61 \pm 0.00$ & $40.54 \pm 0.12$ & & $5.07 \pm 0.02$ & $43.69 \pm 0.21$ & $10.40 \pm 0.06$ & $0.39 \pm 0.00$ & $0.19 \pm 0.01$ & $0.35 \pm 0.00$ & $46.86 \pm 0.14$ & $43.69 \pm 0.21$ & $10.75 \pm 0.06$ \\
\hline $12 \mathrm{CPO}$ & $0.23 \pm 0.00$ & $0.58 \pm 0.00$ & $40.00 \pm 0.11$ & & $5.47 \pm 0.01$ & $42.96 \pm 0.20$ & $10.25 \pm 0.03$ & $0.37 \pm 0.00$ & $0.18 \pm 0.01$ & $0.33 \pm 0.00$ & $45.88 \pm 0.12$ & $43.58 \pm 0.20$ & $10.84 \pm 0.05$ \\
\hline ** & ND-0.5 & $0.5-2.0$ & $39.3-47.5$ & ND-0.6 & $3.5-6.0$ & $36.0-44.0$ & $9.0-12.0$ & ND-1.0 & & ND-0.5 & & & \\
\hline$\star \star \star *$ & $0.1-0.5$ & $0.5-1.5$ & $38.0-43.5$ & ND-0.6 & $3.5-5.0$ & $39.8-46.0$ & $10.0-13.5$ & ND-0.6 & & ND-0.6 & & & \\
\hline
\end{tabular}

Means \pm Standard Error. ND = not detected; * $\mathrm{CPO}(1,2$ and 3$)$ and $\mathrm{CPOL}(4,5$ and 6$)$ were produced by traditional methods in Bahia; CPOL (7) and (CPO) (8,9 and 10) were industrially produced locally, and CPO (11 and 12) were industrially produced in Pará.

${ }^{* *}$ and ${ }^{* * *}=$ ranges of fatty acids for CPO and CPOL, respectively, by CODEX 210, $(2011)$, SFA= saturated fatty acids = MUFA = monounsaturated fatty acids; PUFA= polyunsaturated fatty acids. FAME: fatty acids methyl esters. 
Table 3

Physicochemical parameters of crude palm oil (CPO) and crude palm olein (CPOL) marketed in Salvador-Bahia

\begin{tabular}{cccccc}
\hline Sample* & $\begin{array}{c}\text { Total carotenoids } \\
\left(\boldsymbol{\mu g} \mathbf{~ g}^{-1}\right)\end{array}$ & $\begin{array}{c}\text { Free fatty acid } \\
(\%)\end{array}$ & $\begin{array}{c}\text { Peroxide value } \\
\left(\mathbf{m e q ~}_{\mathbf{2}} \mathbf{K g}^{-1}\right)\end{array}$ & $\begin{array}{c}\text { Induction } \\
\text { time }(\mathbf{h})\end{array}$ & $\begin{array}{c}\text { Total polar } \\
\text { compounds }(\%)\end{array}$ \\
\hline $1 \mathrm{CPO}$ & $578.26 \pm 5.99$ & $9,23 \pm 0.07$ & $1.99 \pm 0.00$ & $4.66 \pm 0.43$ & $16.81 \pm 0.07$ \\
$2 \mathrm{CPO}$ & $457.34 \pm 1.58$ & $10.38 \pm 0.05$ & $2.19 \pm 0.03$ & $2.04 \pm 0.11$ & $19.50 \pm 0.09$ \\
3 CPO & $544.72 \pm 28.53$ & $10.14 \pm 0.05$ & $1.78 \pm 0.00$ & $4.21 \pm 0.05$ & $18.65 \pm 0.05$ \\
$4 \mathrm{CPOL}$ & $505.58 \pm 46.05$ & $7.78 \pm 0.65$ & $1.52 \pm 0.07$ & $3.45 \pm 0.02$ & $16.98 \pm 0.07$ \\
$5 \mathrm{CPOL}$ & $468.33 \pm 25.38$ & $10.20 \pm 0.05$ & $2.18 \pm 0.00$ & $3.80 \pm 0.02$ & $18.14 \pm 0.42$ \\
6 CPOL & $539.10 \pm 7.89$ & $9.12 \pm 0.65$ & $1.19 \pm 0.00$ & $3.80 \pm 0.08$ & $17.36 \pm 0.30$ \\
$7 \mathrm{CPOL}$ & $553.82 \pm 17.77$ & $10.89 \pm 0.07$ & $3.70 \pm 0.07$ & $2.34 \pm 0.21$ & $17.69 \pm 0.22$ \\
8 CPO & $422.10 \pm 14.38$ & $6.83 \pm 0.12$ & $1.32 \pm 0.07$ & $2.45 \pm 0.03$ & $16.92 \pm 0.32$ \\
9 CPO & $571.75 \pm 10.89$ & $13.49 \pm 0.07$ & $1.65 \pm 0.07$ & $1.72 \pm 0.06$ & $19.15 \pm 0.69$ \\
$10 \mathrm{CPO}$ & $584.26 \pm 12.64$ & $6.77 \pm 0.01$ & $1.32 \pm 0.13$ & $3.70 \pm 0.05$ & $13.71 \pm 0.18$ \\
$11 \mathrm{CPO}$ & $938.46 \pm 3.66$ & $2.24 \pm 0.00$ & $0.60 \pm 0.03$ & $13.75 \pm 0.2$ & $9.47 \pm 0.42$ \\
$12 \mathrm{CPO}$ & $940.20 \pm 11.80$ & $2.51 \pm 0.07$ & $0.80 \pm 0.03$ & $13.21 \pm 0.13$ & $10.10 \pm 0.60$ \\
\hline
\end{tabular}

Values are expressed as the mean of triplicate analyses (Total carotenoids, Free fatty acid and Peroxide value) or duplicate (Induction time and Total polar compounds) \pm standard error. ${ }^{*} \mathrm{CPO}(1,2$ and 3$)$ and CPOL $(4,5$ and 6$)$ were produced by traditional methods in Bahia; CPOL (7) and (CPO) (8, 9 and 10) were industrially produced locally, and CPO (11 and 12) were industrially produced in Pará.

harmful effect of fermentation is the continuous buildup of FFA in the mesocarp of the fruit under the action of the lipase (Ebonguea et al., 2006).

Once the fruits are processed, the lipase is no longer active, but the FFA content may continue to increase during storage as a result of autocatalytic hydrolysis (Frank et al., 2011; Idris et al., 1992). In Salvador, oil production and marketing occur in the homes of the processors, along road sides, and in local/periodic market centers and stalls. Retailers and wholesale dealers store their product in open air, packaged in plastic bottles exposed to high light or artificial light intensities, and under conditions of heat and humidity, resulting in high FFA content (Henry, 2011; Nkpa et al., 1990; Akinyeyea et al., 2011).

\subsection{Peroxide values (PV)}

The PV is an indicator of the level of lipid peroxidation or oxidative degradation. The PV for all samples in Table 3 corresponded to normal CODEX 210, (2011) values, which recommend a maximum $\mathrm{PV}$ of $15 \mathrm{meq} \mathrm{O}_{2} \mathrm{~kg}^{-1}$ oil. In this study, the PV ranged from 0.59-3.7 meq $\mathrm{O}_{2} \mathrm{~kg}^{-1}$ oil, and the lowest values were recorded for samples 11 and 12 (Table 3). A PV of 1.94-5.95 was previously reported for Brazilian palm oils Trigueiro and Penteado (1993a). A rancid taste is often noticeable when the PV is between 20 and 40 meq $\mathrm{O}_{2} \mathrm{~kg}^{-1}$ of oil (Ekwenye, 2006). A low PV does not indicate that the oil is good; it only gives an indication (sometimes misleading) of the current state of oxidation of an oil sample and does not indicate the potential for oxidation (Frank et al., 2011).
Studies have shown that PV increases almost linearly with increased storage time, extraction methods and the amount of unsaturated acids (Aletor et al., 1990; Frank et al., 2011). No significant differences were observed among samples 8, 9 and 10 compared to the other samples $(p>0.05)$, with the exception of sample 7 ( $p<0.005)$, which exhibited a higher PV (3.70 \pm 0.07 meq $\mathrm{O}_{2} \mathrm{~kg}^{-1}$ oil). This result is attributable, in part, to prolonged storage at ambient temperature, the traditional extraction method and the lower ratio of saturated/unsaturated acids (0.83) (Tables 1 and 2). The mean values for industrially extracted olein (samples 4, 5, and 6), the industrial Pará oils (samples 11 and 12), and the industrial (samples 8, 9, and 10) and traditional (samples 1, 2, and 3) Bahia oils were 1.63 meq $\mathrm{O}_{2} \mathrm{~kg}^{-1}$ oil $\pm 0.02,0.70$ meq $\mathrm{O}_{2} \mathrm{~kg}^{-1}$ oil $\pm 0.04,1.43$ meq $\mathrm{O}_{2} \mathrm{~kg}^{-1}$ oil \pm 0.09 , and 1.99 meq $\mathrm{O}_{2} \mathrm{~kg}^{-1}$ oil \pm 0.01 , respectively. Thus, technical processing and composition exert a marked influence on the PV.

\subsection{Total polar compounds (TPC)}

The TPC concentration is a good indicator of the overall quality of the initial oil. The TPC include hydrolysis products (polymerized triacylglycerols, oxidized triacylglycerols, diacylglycerols and free fatty acids) (Dobarganes et al., 2000). In general, fresh refined oils contain total polar compounds ranging from $3.2 \%$ to $3.8 \%$, and in many European countries, the maximum value for TPC is $24-27 \%$ for commercial frying oils (Berger, 2005; Marmesat et al., 2012; Dobarganes and Márquez-Ruiz, 1998).

The mean TPC for CPOLs (samples 4, 5, and 6), the traditional CPOL (7), the industrial CPO (samples 
8, 9, and 10) and traditional (samples 1, 2, and 3) Bahia CPO were $17.49 \% \pm 0.26,17.69 \% \pm 0.22$, $16.59 \% \pm 0.40$ and $18.32 \% \pm 0.07$, respectively, which is higher than that of the Pará industrial oil $(9.79 \% \pm 0.51)$ (Table 3$)$. A significant difference was observed $(p<0.05)$ in samples 11 and 12 compared to all other samples. The higher amounts of total polar compounds in palm oils are mainly due to a higher level of diacylglycerol contents (4.0-7.5\%) compared to other vegetable oils (Berger, 2005; DeMarco et al., 2007). In the studies of fractions of palm olein, Plessis and Meredith (1999), Tarmizi and Ismail (2008) and Ismail (2005) determined polar compound values of $7 \%, 6.8-7.7 \%$ and $6 \%$, respectively. In this study, the polar compound values of the samples produced in Bahia were more than double those reported in the literature. These results would appear to be related to the positive correlation between FFA and TPC (Table 4).

\subsection{Total carotenoids (TC)}

Crude palm oil has a dark red-orange color due to its high carotene content (500-1000 mg $\mathrm{kg}^{-1}$ ) (PORAM, 2013). The major carotenoids in palm oil are $\beta$ - and $\alpha$-carotene, and depending on the refining process, palm oil is the world's richest source of natural plant carotenoids in terms of equivalent retinol (pro-vitamin A) (RodriguezAmaya, 1999; Edem, 2002; Sundram et al., 2003).

The amount of carotenoids present in palm oil is influenced by many factors, such as species, variety or hybrid palms. In Brazil, the most common cultivars are Dura, Tenera and Pisifera (Trigueiro and Penteado, 1993b). May (1994) reported carotenoid concentrations of 428 and 997 ppm for the Pisifera and Dura varieties, respectively. The TC of the CPO and CPOLs in our study were within these reported ranges (422.10-940.02 $\left.\mu \mathrm{g} \mathrm{g}^{-1}\right)$ (Table 3). Compared to the other samples, samples 11 and 12 had significantly higher carotenoid contents (Table 3 ). The mean TC of traditional (1, 2, and 3 ) and industrial processed oil (8, 9, and 10) were $526.77 \mu \mathrm{g} \mathrm{g}^{-1} \pm 12.03$ and 526.03 $\mu \mathrm{g} \mathrm{g}^{-1} \pm 12.63$, respectively. These results are in contrast to the results of Aletor et al., (1990), who demonstrated that traditional extraction oils retained more $\beta$-carotene than mechanically processed oils. The explanation was that the palm fruit processed in the traditional manner were not exposed to high temperatures. During the processing techniques employed in Bahia, palm seeds are exposed to sunlight and sterilized long after harvest, resulting in prolonged heating of the crude oil and greater fluctuations in impurity levels. Under these conditions, carotenoid oxidation may be more pronounced (Rodriguez-Amaya, 1999). The quality of the Pará oil which was industrially processed was better than that of Bahia oil, particularly with respect to fruit hygiene, fermentation time and sterilization.

Inverse correlations were observed between FFA and TC ( $r=-0.740)$, TC and TPC $(r=-0.875)$ and TC and PV $(r=-0.521)$ (Table 4). Thus, FFA, TPC and PV are mainly responsible for the low oxidative stability of these oils and likely promote significant carotenoid loss via isomerization (Martin et al., 1999). The oxidation of carotenoids is accelerated by the formation of lipid hydroperoxides resulting from oxidation, leading to discoloration and clarification, with the formation of $\alpha$ - and $\beta$-ionones, $\beta-13$ and $\beta-14$ apocarotenals and $\beta-13$ apocrotenone, among other carotenoids (Sambanthamurthi et al., 2000).

\subsection{Changes in oxidative stability}

The Rancimat method is frequently used to evaluate and predict oxidative stabilities under heating conditions, known as the induction time (Rauen-Miguel et al., 1992). Clearly distinct results were observed for all of the samples $(1.72-13.75 \mathrm{~h})$ (Table 3$)$. The samples did not differ among themselves $(p>0.05)$ with respect to this parameter, with the exception of samples 7 and $11(p<0.041), 5$ and $8(p<0.048)$ and 2 and 12 ( $p<0.018)$. Anwar et al., (2003) analyzed various vegetable oils and fats and concluded

Table 4

Statistically significant Spearman's correlations between physicochemical parameters of oils marketed in Salvador - Bahia

\begin{tabular}{|c|c|c|c|c|c|}
\hline & & $\begin{array}{l}\text { Free fatty acid } \\
\qquad(\%) \\
\end{array}$ & $\begin{array}{c}\text { Peroxide value } \\
\text { (meq } \mathrm{O}_{2} \mathrm{Kg}^{-1} \text { oil) }\end{array}$ & $\begin{array}{l}\text { Total carotenoids } \\
\qquad\left(\mu \mathrm{g} \mathrm{g}^{-1}\right)\end{array}$ & $\begin{array}{c}\text { Induction } \\
\text { time (h) }\end{array}$ \\
\hline $\begin{array}{l}\text { Peroxide value } \\
\text { (meq } \mathrm{O}_{2} \mathrm{Kg}^{-1} \text { oil) }\end{array}$ & $r$ & $\begin{array}{l}\mathbf{0 , 6 7 5}\left({ }^{* *}\right) \\
0,00\end{array}$ & & & \\
\hline $\begin{array}{l}\text { Total carotenoids } \\
\qquad\left(\mu \mathrm{g} \mathrm{g}^{-1}\right)\end{array}$ & $r$ & $\begin{array}{l}-0,740\left({ }^{* *}\right) \\
0,00\end{array}$ & $\begin{array}{l}\left.-0,5211^{* \star}\right) \\
0,001\end{array}$ & & \\
\hline $\begin{array}{l}\text { Induction time } \\
\text { (h) }\end{array}$ & $r$ & $\begin{array}{l}-0,858\left(^{(*}\right) \\
0,00\end{array}$ & $\begin{array}{l}-0,598\left(^{* \star}\right) \\
0,002\end{array}$ & $\begin{array}{l}0,937\left(^{* \star}\right) \\
0,00\end{array}$ & \\
\hline $\begin{array}{l}\text { Total polar compounds } \\
\qquad(\%)\end{array}$ & $r$ & $\begin{array}{l}0,927\left({ }^{\star *}\right) \\
0,00\end{array}$ & $\begin{array}{l}0,613\left({ }^{* \star}\right) \\
0,001\end{array}$ & $\begin{array}{l}-0,875\left(^{\star \star}\right) \\
0,00\end{array}$ & $\begin{array}{l}-0,909\left(^{* *}\right) \\
0,00\end{array}$ \\
\hline
\end{tabular}

The numbers above represent Spearman's correlation ( $r$ ), and the ones below are the statistical significance. ${ }^{* *}$ mean that correlations are significant at 0.05 level. 
that palm oil and vaspanati had a longer induction period than other fats and oils, ranging from 10.00 to $15.47 \mathrm{~h}$. In this study, all samples produced in the state of Bahia displayed induction times shorter than expected for crude palm oil (Hadi et al., 2012). The oxidative stability of oils is affected by the concentration and stability of antioxidants in the oil and the presence of prooxidant compounds, such as free fatty acids, lipid peroxides, or pro-oxidant metals (Lin, 2011, Marmesat et al., 2010). Accordingly, there was a significant positive correlation between carotenoids and IT $(r=0.937)$ and an inverse correlation between IT and FFA $(r=-0.858)$, IT and PV $(r=-0.598)$ and IT and TPC $(r=-0.909)$ (Table 4).

\section{CONCLUSIONS}

The analysis of fatty acids revealed a wide variation and, as expected, the CPOLs were more unsaturated than the CPO. All oils produced in Bahia displayed higher FFA, PV and TPC content and decreased IT and TC content when compared to samples obtained by industrial extraction in Pará. The levels of FFA and TPC in the samples produced in Bahia were not within international quality standards. Thus, we conclude that both extraction methods employed in this region produce an oil of poor quality.

Considering that these palm oils may be marketed in Bahia within a minimum of 18 months, it is likely that a significant increase in the degradation indicators may occur during this period, making the oil even more unsuitable for human consumption. Given that crude palm oil is a major ingredient of akara and other dishes, these results are a clear indication that palm oil production in Bahia is in need of improvement with respect to fruit harvesting, handling, transport, storage and hygiene, as well as extraction techniques. The oxidative stability of crude palm oil and olein should be investigated to establish a shelf life for these products.

\section{ACKNOWLEDGEMENTS}

The authors are thankful for financial support from CNPq (Process no 482852/20070 and 482790/2010-5) and FAPESB (Termo №: BOL1784/2010) and for support from the Associação das Baianas de Acarajés e Mingau da Cidade de Salvador-Bahia-Brazil.

\section{REFERENCES}

Akinyeyea RO, Adeyeye El, Fasakina O, Agboolaa A. 2011. Physico-chemical properties and anti-nutritional factors of palm fruit products (Elaeis Guineensis Jacq.) from Ekiti State Nigeria. Electron. J. Environ. Agric. Food Chem. 10, 2190-2198.
Akusu MO, Achinewhu SC, Mitchell J. 2000. Quality attributes and storage stability of locally and mechanically extracted crude palm oils in selected communities in Rivers and Bayelsa States, Nigeria. Plant Foods Hum. Nutr. 55, 119-126.

Aletor VA, Ikhena AF, Egharevba V. 1990. The quality of some locally processed nigerian palm oils: an estimation of some critical processing variables. Food Chem. 36, 311-317.

Anwar F, Bhanger MI, Kazib TG. 2003. Relationship between Rancimat and Active Oxygen Method Values at Varying Temperatures for Several Oils and Fats. J. Am. Oil Chem. Soc. 80, 151-155.

AOCS. 1990. Official methods and recommended practices of the American Oil Chemists' Society. 4th ed. Champaign, USA, AOCS. [AOCS Official method Cd 8-53].

AOCS. 1992. Official methods and recommended practices of the American Oil Chemists' Society. 4th ed. Champaign, USA, AOCS. [AOCS Official method $\mathrm{Ca}$ 5a-40].

Berger KG. 2005. The use of palm oil in frying. Frying oil series. Malaysian Palm Oil Promotion Council (MPOPC). Available at http://www.mpoc.org.

Codex alimentarius. 1999. Norma del CODEX para aceites vegetales especificados (Codex STAN 2101999). Revisión 2011.

Curvelo FM. 2010. Uma Imersão no Tabuleiro da Baiana: O Estudo do Óleo de Palma Bruto (Elaeis guineensis). Dissertação de Mestrado da Universidade Federal da Bahia, Brasil, 13-103.

Davies BH. 1976. Carotenoids. In: L.W.T Goodwin (Ed.), Chemistry and Biochemistry of Plant Pigments. Academic Press. London, 38-165.

Demarco E, Saravese M, Parisini C, Battimo I, Falco S, Sacchi R. 2007. Frying performance of a sunflower/ palm oil blend in comparison with pure palm oil. Eur. J. Lipids Sci. Technol. 109, 237-246.

Dobarganes MC, Velasco J, Dieffenbacher A. 2000. Determination of polar compounds polymerized and oxidized triacylglycerols, and diacylglycerols in oils and fats. Pure Appl. Chem. 72, 1563-1575.

Dobarganes MC, Márquez-Ruiz. 1998. Regulation of used frying fats of quick tests for discarding the fats. Grasas Aceites 49, 331-335.

Ebonguea GFN, Dhouibc R, Carrièrec F, Amvam Zollob $\mathrm{PH}$, Arondelc V. 2006. Assaying lipase activity from oil palm fruit (Elaeis guineensis Jacq.) mesocarp. Plant Physiol. Bioch. 44, 611-617.

Edem DO. 2002. Palm oil: Biochemical, physiological, nutritional, hematological, and toxicological aspects: A review. Plant Foods Hum. Nutr. 57, 319-341.

Ekwenye UN. 2006. Chemical characteristics of palm oil biodeterioration. Biokemistri, 18, 141-149.

Frank NEG, Albert MME, Ekwe D. 2011. Assessment of the quality of crude palm oil from smallholders in Cameroon. J. Stored Prod. Postharvest Res. 2, 52-58.

Gomes M, Biondi A, Brianezi T, Glass V. 2008. O Brasil dos Agrocombustíveis: Impactos das lavouras sobre a terra, o meio e a sociedade: Palmáceas, Algodão, Milho e Pinhão-Manso. São Paulo: Repórter Brasil, Centro de Monitoramento de Agrocombustíveis. Available at http:// www.reporterbrasil.org.br/documentos/o_brasil_dos_ agrocombustiveis_v2.pdf.

Hadi NA, Han NM, May CY, Ngan MA. 2012. Dry Heating of Palm Fruits: Effect on Selected Parameters. Am. J. Eng. Appl. Sci. 5, 128-131. 
Henry OH. 2011. Monitoring the Free Fatty Acid Level of Crude Palm Oil Stored under Light of Different Wavelenghts. Am. J. Food Technol. 6, 701-704.

Idris NA, Abdullah A, Halim AH. 1992. Evaluation of palm oil quality: Correlating sensory with chemical analyses. J. Am. Oil Chem. Soc. 69, 272-275.

IAL. Instituto Adolfo Lutz. 2005. Óleos e gorduras, en IAL (4aㅡ ed.) Métodos físicos-químicos para análise de alimentos. Instituto Adolfo Lutz, São Paulo, 4-989.

IPHAN-Instituto do Patrimônio Histórico e Artístico Nacional. 2005. DOSSIE IPHAN 6: Ofício das Baianas do Acarajé. Ministério da Cultura, DF, Brasil. Available at http://portal.iphan.gov.br/portal/ baixaFcdAnexo.do?id=919.

Ismail R. 2005. Palm oil and palm olein frying applications. Asian Pac. J. Clin. Nutr. 4, 414-419.

Läubli MW, Bruttel PA. 1986. Determination of the oxidative stability of fats and oils: Comparison between the active oxygen method (AOCS Cd 12-57) and the rancimat method. J. Am. Oil Chem. Soc. 63, 792-795.

Lin SW. Palm oil. 2011. Palm oil, en F.D. Gunstone (1th Ed.). Vegetable oils in food technology: composition, properties and use. Blackwell Publishing, lowa, 5993.

Marmesat S, Morales A, Velasco J, Dobarganes MC. 2010. Action and fate of natural and synthetic antioxidants during frying. Grasas Aceites 61, 333340.

Marmesat S, Morales A, Velasco J, Dobarganes MC. 2012. Influence of fatty acid composition on chemical changes in blends of sunflower oils during thermoxidation and frying. Food Chem. 135, 23332339.

Martin HD, Ruck IC, Schmidt M, Sell S, Beutner B, Mayer B, Walsh R. 1999. Chemistry of carotenoid oxidation and free radical reactions. Pure Appl. Chem. 71, 2253-2262.

May CY. 1994. Palm oil carotenoids. Food Nutr. B. 15, 130-137.

Mesquita AS. 2002. Do azeite de dendê de ogum ao palm oil commodity: uma oportunidade que a Bahia não pode perder. Bahia Agric. 5, 22-27.
Nkpa NN, Osanu FC, Arowolo, TA. 1990. Effect of packaging materials on storage stability of crude palm oil. J. Am. Oil Chem. Soc. 67, 259-263.

Plessis LM, Meredith AJ. 1999. Palm olein quality parameter changes during industrial production of potato chips. J. Am. Oil Chem. Soc. 76, 731-738.

PORAM-Palm OilRefiners Association of Malaysia. Standard Specifications for Crude Palm Oil, Available at: http:// www.poram.org.my/database/contract/specifications. htm.

Rauen-Miguel AMO, Esteves W, Barrera-Arellano D. 1992. Determinación del período de inducción de aceite de soja - Correlación entre el Rancimat y otros índices. Grasas Aceites 43, 119-122.

Rodriguez-Amaya DB. 1999. Changes in carotenoids during processing and storage of foods. Arch. Latinoam. Nutr. 49, 38S-47S.

Sambanthamurthi R, Sundram K, Tan, YA. 2000. Chemistry and biochemistry of palm oil. Prog. Lipid Res. 39, 507-558.

Sudram K, Sambanthamurthi R, Tan, Y. 2003. Palm fruit chemistry and nutrition. Asia Pac. J. Clin. Nutr. 12, 355-362.

Tarmizi AHAE, Ismail R. 2008. Comparison of the frying stability of standard palm olein and special quality palm olein. J. Am. Oil Chem. Soc. 85, 3, 245-251.

Tavares M, Barbério JC. 1989. Composição em ácidos graxos do azeite de dendê (Elaeis guineensis Jacq.) brasileiro. Rev Farm. Bioqui. São Paulo. 25, 5-15.

Trigueiro INS, Penteado MVC. 1993a. Características físicas, químicas e estado de oxidação de óleos de dendê brasileiros. B. CEPPA. 11, 103-112.

Trigueiro INS, Penteado MVC. 1993b. Mudanças nos teores de alfa e beta caroteno em óleo dendê durante armazenamento em temperatura ambiente $\left(26^{\circ} \mathrm{C}\right)$. B. CEPPA.11, 103-112.

Visentainer JV, Franco, MRB. 2012. Quantificação de ácidos graxos utilizando padronização interna, en 2 ${ }^{a}$ (Ed.). Ácidos graxos em óleos e gorduras: Identificação e quantificação. Varela, São Paulo, 9-120.

Recibido: 6/11/12 Aceptado: 04/03/13 